\title{
OCCURRENCE OF ENDOPARASITES IN SOME SELECTED FISHES OF CHENAB RIVER, PAKISTAN
}

Fehmeeda Bibi*, Shafqat Nawaz Qaisrani ${ }^{1}$, Mazhar Ayaz, Mudasser Nazir, Atif Nisar Ahmad, Mian Muhammad Awais, Bushra Nisar Khan² and Masood Akhtar

Faculty of Veterinary Sciences, Bahauddin Zakariya University, Multan, Pakistan

\begin{abstract}
The current study was carried out to evaluate prevalence of endoparasites in freshwater fishes of Chenab River. The fish samples were collected from Chenab River during November 2014 to March 2015. In total, 285 fishes were examined for parasites, of which 75 fishes $(26.1 \%$ of the total sample) were infected with parasites. Among the species, prevalence of infection was maximum in Rita rita (60\%) and in Labeo rohita $(37.5 \%)$. The minimum prevalence was, however, recorded in Oreochromis aureus (16.7\%) and no parasite was found in Mastacembatus armatus. Among the organs, highest prevalence of endoparasites was observed in the intestine (43\%) and gall bladder $(33.2 \%)$. The prevalence of nematode and trematode was found higher (29 and $21 \%$, respectively) in all fishes. It was revealed that the diversity of endoparasites in freshwater fishes is high. Since the use of fish as a ready source of food is increasing, therefore, the overall health status of fish in a system is becoming more valuable.
\end{abstract}

Key words: Endoparasites, freshwater fish, Labeo rohita, prevalence, Rita rita

\section{INTRODUCTION}

Fish is an important source of food that supplies low cholesterol protein to approximately $60 \%$ of the world population (Sichewo et al. 2013). Developing countries deriving approximately $30 \%$ of their annual animal protein requirements from fish (Abisoye et al. 2011). Both wild and farm fish are a potential host to various parasitic species that cause greater mortalities. It has been reported that at least one parasite is hosted by approximately 50 to $90 \%$ of freshwater fishes (Eissa et al. 2012). Losses resulting from these parasites are at high densities under existing conditions and, if left uncontrolled, may lead to catastrophic proportions (Abbas et al. 2014). The normal growth of fish is affected by parasites that lives on the fish if highly infested. Parasites not only effect the survival of fish directly by reduced condition (fish size), changing the behavior, further susceptible to infection (Thomas, 2014), but also lowered swimming ability, decrease their growth rate and increase mortalities (Piasecki

*Author for correspondence: <fehmeeda.bibi@bzu.edu.pk>. ${ }^{1}$ Department of Animal Nutrition, University of Veterinary and Animal Sciences, Lahore, Pakistan. ${ }^{2}$ Department of Zoology, University of the Punjab, Lahore, Pakistan.

(c) 2018 Zoological Society of Bangladesh DOI: http://dx.doi.org/10.3329/bjz.v46i1.37626 
et al. 2004). In crowded environments, the parasitic infections are considered a major problem (Van den Broek 1979). Parasites affects yield of various organs of fish including liver oils (Cross 1933). To prevent the negative effects of parasitic diseases, the precise identification of fish parasites is imperative.

Parasites, specially, occurring in freshwater fishes need serious consideration that contaminate economically imperative fish species that, in many cases, it decrease their quality and deliciousness (Okorie 1972). It is necessary to understand the mode of transmission and potential intermediate hosts to eradicate the problem (Goselle et al. 2008). Parasitism is most common and diverse in wild than in ponds, hatcheries and captivity. Infection in fishes occurs due to overcrowding and environmental stress (Thomas 2014). In Pakistan, fish culture has transformed into a main commercial activity during the last two decades. Intensification and expansion of fish culture is, however, facing severe threats from pathogens including parasites as they are one of the major causes for chronic mortalities and poor growth, affecting the yield and marketability of fishes.

Fish parasites may be transmitted through food, introduction of exotic species in aquatic ecosystem as well as handling and processing of the infected fish. Fish infections caused by endoparasitic helminths tends to increase with increased level of pollution (Palm 2011).

Fish become infected with parasites if they are nurtured live foods containing infective life stages that carry the infective stages of vector (Yanong 2011). Through variation in the aquatic environment, either environmental or anthropogenic, can alter host parasite balance and become source of disease or mortality in fishes. Fish parasites cause physiological, reproductive and physical damage to fishes (Iwanowicz 2011). The consumption of contaminated fish may lead to food borne illness (diarrhea and dysentery) resulting in great economic losses (Sichewo et al. 2013). Both ecto and endoparasites are common in fishes but endoparasites are more dangerous and cause extensive damage to their hosts (Ashraf and Zafar 2013). The awareness regarding numerous common fish parasites within a given fish population is necessary. The aim of the study is, therefore to identify and detect the endoparasites of freshwater fishes from Chenab River and to investigate the prevalence of endoparasites.

\section{MATERIAL AND METHODS}

A total of 285 fishes were randomly collected from two different location; Shershah Bridge and Head Muhammad Wala at Chenab River, Pakistan. Fishes were caught by using or through gillnets by local fisherman during November, 2014 to March, 2015. The samples were transported immediately to the 
Parasitology Laboratory at Faculty of Veterinary Sciences, Bahauddin Zakariya University, Multan for further investigation of parasites.

Fishes were identified according to the method described by Mirza and Sandhu (2007). Weight and length of each fish were recorded. After removal of excess mucus, the samples were dissected by making an incision along the midventral line by using scalpel, thumb forceps and sharp-blunt scissors. The endoparasites were collected from different locations including liver, intestine, gall bladder and stomach. After examining the external surface of each organ, the organ was dissected for further examination, was taken. A drop of water was placed in the middle of a clean and dry glass slide, free from scratches, and a small amount of sample material (intestine, liver, stomach or gall bladder) was added on it. The material was mixed with glass rod and spreaded thinly, thereafter, covered with a coverslip. The prepared slide was examined under microscope (Olympus) for parasite, their eggs or larvae.

Prevalence: Prevalence of endoparasites in freshwater fish was measured by following formulae.

$$
\text { Prevalence }(\%)=\frac{\text { No. of infected fish }}{\text { Total No. of fish examined }} \times 100
$$

\section{RESULTS AND DISCUSSION}

In total, 285 fish sample were collected from Chenab River. The collected fish samples included Labeo rohita, Catla catla, Hypophthalmichthys molitrix, Rita rita, Ctenopharyngodon idella, Notopterous notopterous, Mastacembatus armatus, Channa punctata and Oreochromis aureus species (Table 1). The parasites found in fish are shown in Table 1. A negative correlation was observed with the size of fish and prevalence of endoparasites. Maximum prevalence of endoparasite was recorded in Rita rita (60\%) followed by Labeo rohita species with $37.5 \%$ (Table 1).

In total, 24 identified parasites belonging to 21 species, and eight classes including Trematoda, Nematoda, Conoidasida, Microsporidea, Cestoidea, Copepoda, Monogenea and Myxospora were recovered from the stomach, intestine, liver, and gall bladder. Among the parasitic classes, the highest prevalence of Nematoda (29\%) followed by Trematoda (21\%) was observed (Table 2).

In total, 285 fishes were investigated for endoparasites during the present study. The results indicated that 75 fishes (26.3\% of the total sample) were infected with endoparasites. The highest incidence of endoparasites was observed in Rita rita (60\%) and Labeo rohita (37.5\%), whereas. the minimum prevalence was recorded in Oreochromis aureus (16.7\%) and no parasite was 


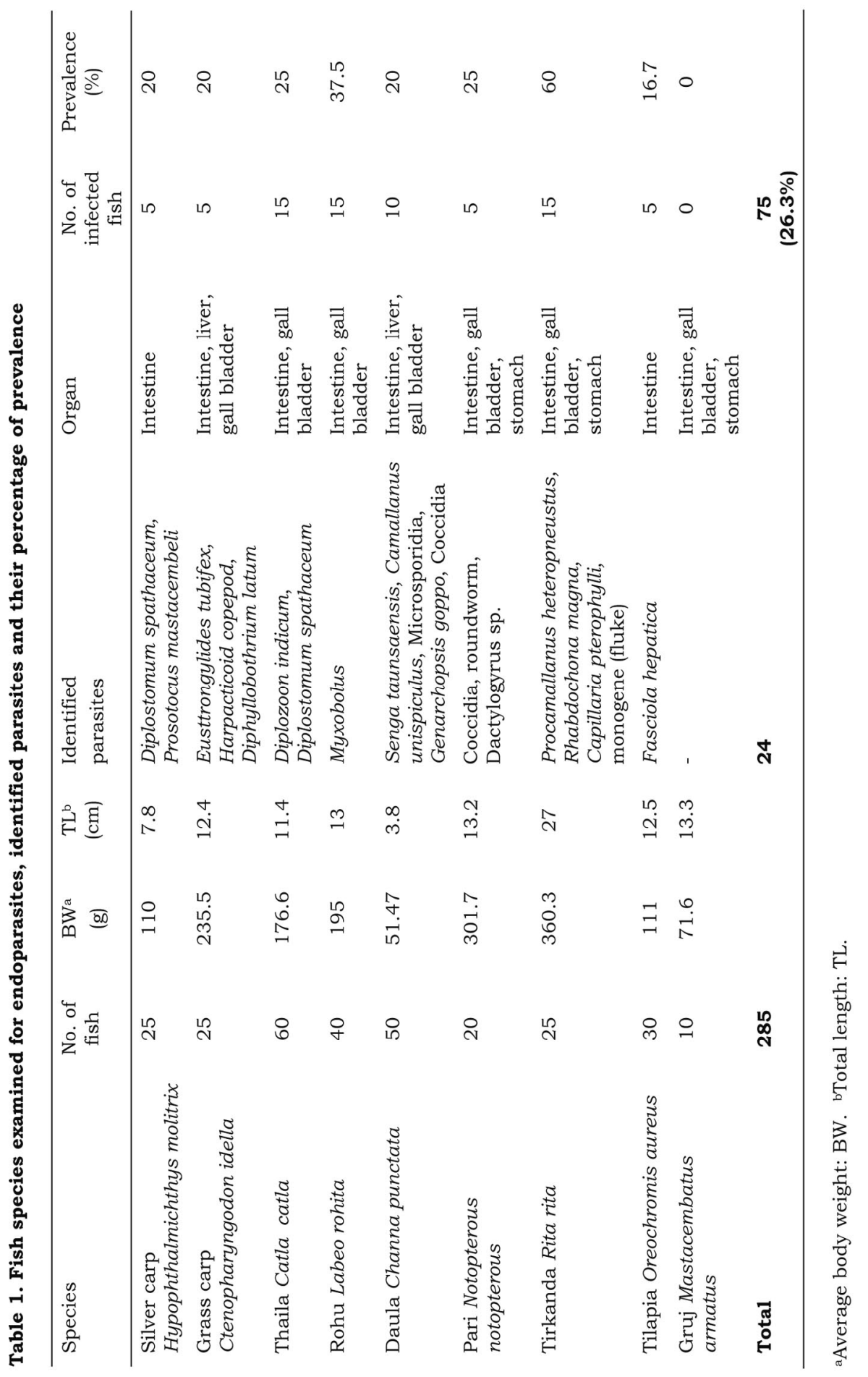


found in Mastacembatus armatus (Table 1). Among the organs, the highest prevalence was observed in intestine (43\% of the total identified parasites) and gall bladder $(33.2 \%$ of the total parasites) of the examined freshwater fishes (Fig. 1).

Table 2. Prevalence of endoparasites with respect to their class in freshwater fish of Chenab River

\begin{tabular}{|c|c|c|c|}
\hline Class & Parasites recovered & $\begin{array}{l}\text { No. of parasites } \\
\text { species }\end{array}$ & $\begin{array}{l}\text { Prevalence } \\
\text { (\%) }\end{array}$ \\
\hline \multirow{5}{*}{ Trematoda } & Genarchopsis goppo & \multirow{5}{*}{5} & \multirow{5}{*}{21} \\
\hline & Diplostomum spathaceum & & \\
\hline & Prosotocus mastacembeli & & \\
\hline & Diplostomum spathaceum & & \\
\hline & Fasciola hepatica & & \\
\hline \multirow{6}{*}{ Nematoda } & Capillaria pterophylli & \multirow{6}{*}{7} & \multirow{6}{*}{29} \\
\hline & Rhabdochona magna & & \\
\hline & Procamallanus heteropneustus & & \\
\hline & Roundworm & & \\
\hline & Camallanus unispiculus, & & \\
\hline & Eusttrongylides tubifex & & \\
\hline \multirow{2}{*}{ Conoidasida } & Coccidia & \multirow{2}{*}{3} & \multirow{2}{*}{13} \\
\hline & Isospora & & \\
\hline Microsporidea & Microsporidia & 2 & 8 \\
\hline \multirow{2}{*}{ Cestoidea } & Senga taunsaensis & \multirow{2}{*}{2} & \multirow{2}{*}{8} \\
\hline & Diphyllobothrium latum & & \\
\hline \multirow[t]{2}{*}{ Copepoda } & Harpacticoid copepod & \multirow[t]{2}{*}{1} & \multirow[t]{2}{*}{4} \\
\hline & Dactylogyrus spp. & & \\
\hline \multirow[t]{2}{*}{ Monogenea } & Monogene & \multirow[t]{2}{*}{3} & \multirow[t]{2}{*}{13} \\
\hline & Diplozoon indicum & & \\
\hline Myxosporea & Myxobolus & 1 & 4 \\
\hline
\end{tabular}

Fish endoparasites have been of great concern. These parasites continually infect fish which may lead to reduction in growth and increase susceptibility to disease. Overall $26.3 \%$ of the collected samples of freshwater fishes were found infected by endoparasites, whereas, no parasite was found in Mastacembatus armatus. In intestine (40\% of the examined fish) and gall bladder (28.5\% of the examined fish) highest number of parasites was observed. Majority of fishes carry heavy burden of parasitic infestation, which causes deterioration in the food value of fish. Rita rita showed a high rate (60\%) of infection. It was also observed that in Rita rita, Labeo rohita and Catla catla parasite infection increased with length of fish. There are reports indicating that parasitic infection 
is directly proportional to the fish length such as in herring fish, Parophyrs velutus, Clupea harengus, Merluccius gayi (Olson 1978, Carvajal et al. 1979). The positive allometric growth in $T$. zillii and $O$. urolepis urolepis species was observed by Nehemia et al. (2012). As the growth pattern is changed in size (weight and length) that deals with body proportion. Growth pattern is useful in monitoring the state of health of fish species (Oso et al. 2016, Kumary and Raj 2016). The results reported by Pandey et al. (2012) whereas are not in line with these findings. This discrepency in the results may be due to the offered feed composition and attained immunity with the age of fish. In the present study, highest parasitic infestation was observed in large size fish whereas Pandey et al. (2012) reported highest parasitic infection in middle sized and lowers helminthes susceptibility in small and large size fishes. The reported overall prevalence of internal parasites of fish was 17.9\% in Karachi Fish Harbour, 18.5\% at Niger Delta Tidal Creek and 20.83\% at Lake Ziway, respectively (Gasim and Ayub 2012, Ogbeibu et al. 2014, Bekele and Hussien 2015).



Fig. 1. Original distribution of parasites in freshwater fishes of Chenab River.

Difference in prevalence of parasites in fishes may be due to the feeding habits of the host fish, population density, their life span, moving through various habitats, change in the environmental conditions and body size (Berra 2001). Additionally, Khanum et al. (2008) reported that $50 \%$ of the $R$. rita were infected with parasite infestation and this infection was greater in females than in males. A study, similarly, was conducted by Ali et al. (2014) on prevalence of parasites in cultureable fish species of Pakistan. The later author recorded 
maximum prevalence of parasites (35\%) from fish samples that was collected from Muzaffargarh.

Many factors including physiological and biological features of a host determine the parasitic composition of a fish (Khanum et al. 2008). There is dearth of information, however, regarding distribution, pathogenic effects and control of most of the parasitic diseases in natural population of fresh water fish. Many specimens of larvae and adults of cestode were found in intestine of C. carpio with a prevalence of 2\% (Mama and Abdullah 2014). The highest abundance of parasites $(48 \%)$ in Labeo rohita was recorded in November, whereas this parasitic infestation was $44.2 \%$ in October and $46.4 \%$ in December. It has been reported that Dactylogyrus causes damage to the gill filaments of fishes and Gyrodactylus mainly causes damage to skin and fin which is a potential threat to fish culture (Hoffman 1999). The distribution of parasites in organs were found to be maximum in intestine (48.9\%), whereas the stomach contains $31.9 \%$ and minimum (4.3\%) parasites were in swim bladder (Gasim and Ayub 2012). Pollutants may increase parasitism by enhancing host susceptibility or by increasing the number of secondary hosts and vectors (Lafferty and Kuris 1999). The increase in parasitic population may be due to climatic variation, disturbances caused by farming or construction (Peek 2012).

\section{CONCLUSIONS}

Majority of fishes, including Rita rita, Labeo rohita and Catla catla, were carrying heavy parasitic infestation. Among organal distribution, highest prevalence of endoparasites was observed in intestine and gall bladder. The fauna of nematode and trematode were found greater in intestine of freshwater fishes of Chenab River. The present study showed that the diversity of endoparasites in freshwater fishes is high. Studies are, therefore, needed to summarize the impact of endoparasites in infected fish, with particular attention to freshwater fishes in human.

Acknowledgement: The authors gratefully acknowledge the authority of Bahauddin Zakariya University, Multan for providing funds for this study under the Research Grant 2014-2015 programme.

\section{LITERATURE CITED}

ABBAS, F., ASHRAF, M., HAFEEZ-UR-REHMAN, M., IQBAL, K.J., ABBAS, S. and JAVID, A. 2014. Lernaea susceptibility, infestation and its treatment in indigenous major and exotic Chinese carps under polyculture system. Pakakistan Journal of Zoology 46: 1215-1222.

ABISOYE, B.F., OJO, S.K.S., ADEYEMI, R.S. and OLAJUYIGBE, O.O. 2011. Bacteriological assessment of some commonly sold fishes in Lagos metropolis market Nigeria. Prime Journal of Microbiology Research 1: 23-26. 
ALI, A., HAYAT, S., AHMED, M.S., ELAHI, N., SAGHIR, A., ALI, H. and KHAN, W.A. 2014. Prevalence of lernaeid ectoparasites in some culturable Fish species from different Nurseries of Punjab. Biologia (Pakistan) 60: 123-127.

ASHRAF, M. and ZAFAR, A. 2013. Size and organ specificity of different parasites in wild Labeo rohita. International Journal of Emerging Trends in Pharmaceutical Sciences 1: 26-32.

BERRA, T.M. 2001. Freshwater fish distribution. Academic Press.

CARVAJAL, J., CATTAN, P.E., CASTILlO, C. and SCHATTE, P. 1979. Larval anisakids and other helminths in the hake, Merluccius gayi (Guichenot) from Chile. Journal of Fish Biology 15: 671-677.

EISSA, I., ZAKI, V., NADIA, G. and ZAKI, M. 2012. Studies on prevailing cestodiasis in wild African catfish Clarias gariepinus at Kafr El-Sheikh governorate. Life Science Journal 9: 506-511.

F.A.O. 1997. The State of fish: Aquaculture. Food and Agriculture Organization. Rome.

GOSElle, O., SHIR, G., UDEH, E., ABELAU, M. and IMANDEH, G. 2008. Helminth parasites of Clarias gariepinus and Tilapia zilli at Lamingo dam, Jos, Nigeria. Science World Journal 3: 23-28.

HOFFMAN, G.L. 1999. Parasites of North American freshwater fishes. Cornell University Press.

IWANOWICZ, D.D. 2011. Overview on the effects of parasites on fish health. In: Proceedings of the Third Bilateral Conference between Russia and the United States, 12-20 July, 2009, held in Shepherdstown, West Virginia. Landover, Maryland, USA. Khaled bin Sultan Living Oceans Foundation. R.C. Cipriano, A.W. Bruckner, and I.S. Shchelkunov (Eds.), Bridging America and Russia with Shared Perspectives on Aquatic Animal Health, pp. 176-184.

KHANUM, H., FERDOWS, J. and FARHANA, R. 2008. Community of Helminth Parasites in Rita rita (Hamilton Buchanun). Journal of Bioscience 16: 133-135.

KUMARY, K.A. and RAJ, S. (2016). Length-weight relationship and condition of climbing perch Anabas testudineus Bloch population in Kuttanad, Kerala. International Journal of Advanced Research in Biological Sciences 3: 21-26.

LAFFERTY, K.D. and KURIS, A.M. 1999. How environmental stress affects the impacts of parasites. Limnology Oceanography 44: 925-931.

MAMA, K.S. and ABDULLAH, S.M. 2014. Parasitic infections of the common carp Cyprinus carpio from lesser Zab River in Kurdistan region, Iraq. European Scientific Journal 9: 895-900.

MIRZA, M. and SANDHU, A. 2007. Fish of the Punjab, Pakistan. Polymer Publication, Lahore, Pakistan. pp.1-69.

NEHEMIA, A., MAGANIRA, J.D. and RUMISHA, C. 2012. Length-Weight relationship and condition factor of tilapia species grown in marine and fresh water ponds. The Agriculture and Biology Journal of North America 3: 117-124.

OGBEIBU, A.E., OKAKA, C.E. and ORIBHABOR, B.J. 2014. Gastrointestinal helminth parasites community of fish species in a Niger Delta Tidal Creek, Nigeria. Journal of Ecosystems 2014: 01-10.

OKORIE, O.O. 1972. Some major unsolved aspects of the dynamics of African Fisheries as related to questions of rational development and management. The African Journal Tropical Hydrobiology Fisheries, edit. Okedi special Issue, I. E. Africans literature Bureaux. pp. 27-33.

OLSON, R.E. 1978. Parasitology of English sole, Parophrys vetulus Girard in Oregon, USA. Journal of Fish Biology 13: 237-248.

OSO, J.A. and IWALAYE, A.O. 2016. Growth Pattern and Condition Factor (K) of Four Dominant Fish Species in Ero Dam in Ekiti State, Nigeria. British Journal of Applied Research 1: 08-10. 
PALM, H.W. 2011. Fish Parasites as Biological Indicators in a Changing World: Can We Monitor Environmental Impact and Climate Change?. Progress in Parasitology. Springer Berlin Heidelberg. pp: 223-250.

PANDEY, M., SAXENA, R. and HANDA, P. 2012. Demography of helminth parasites in relation to biometic characteristics of Mastacembalus armatus. Journal of Applied and Natural Science 4: 56-59.

PEEK, J.L. 2012. Ectoparasites and intestinal endoparasites in channel catfish, Ictalurus punctatus, in the Blackwater River Missouri. University of Central Missouri.

PIASECKI, W., GOODWIN, A.E., EIRAS, J.C. and NOWAK, B.F. 2004. Importance of copepoda in freshwater aquaculture. Zoological Studies 43: 193-205.

QASIM, S. and AYUB, Z. 2012. Prevalence and intensity of arasites in edible fishes landing at Karachi Fish Harbour. Pakistan Journal of Zoology 44: 1467-1471.

SICHEWO, P.R., GONO, R.K. and SIZANOBUHLE, J.V.M.N. 2013. Isolation and Identification of Pathogenic Bacteria in Edible Fish: A Case Study of Fletcher Dam in Gweru, Zimbabwe. International Journal of Science and Research 2: 269-273.

THOMAS, H. 2014. Direct and indirect effects of a trematode parasite on the endemic freshwater fish Galaxias anomalus (Thesis, Master of Science). University of Otago.

Van Den Broek, W. 1979. A seasonal survey of fish populations in the lower Medway Estuary, Kent, based on power station screen samples. Estuarine and Coastal Marine Sciences 9: 1-15.

YANONG, R.P. 2011. Nematode (Roundworm) infections in fish. IFAS Extension, University of Florida. pp. 8.

(Manuscript received on 20 March, 2018; revised on 27 June, 2018) 